\title{
Publicity in the Regulation of Municipal Services
}

\author{
Olga V. Yakhina \\ Julia S. Yaichnikova \\ Tatiana N. Mikheeva \\ Mari State University, Yoshkar-Ola, Russia \\ Email: olgeens@mail.ru
}

\section{Doi:10.5901/mjss.2015.v6n3s7p59}

\section{Abstract}

\begin{abstract}
The article considers the publicity principle associated with legal control of municipal services. People's trust in local authorities depends considerably not only on the quality of services, but also on the openness of their provision process and citizens' awareness. Publicity covers these categories. The object of this work is to analyze a legal basis controlling publicity in providing municipal services. The research uses a system of general scientific and special juridical methods, including analysis, legal comparison, linguistic and legal techniques. The authors have analyzed the interpretation of the notion "publicity" by Russian scholars and their foreign colleagues who use the term "transparency" and elicited the elements of these principles. They distinguished general approaches to this legal phenomenon and defined differences. The analysis of acting legislation was carried out on the subject of the research. The authors referred to the confirmation of publicity principle at the local level. Special attention was paid to legal acts regulating municipal services at the local level, i.e. administrative regulations. To accomplish the stated objective the authors referred to the Russian and foreign legislation. Based on the research findings, the drawbacks were found in the acting legal control of publicity principle when regulating municipal services. To solve a legal issue the authors submitted acting legislation amendments based on the positive foreign experience of legal control of administrative regulation publicity at the local level.
\end{abstract}

Keywords: publicity, local self-government, municipal services, administrative regulations of local self-government bodies

\section{Introduction}

Successful development of the state is possible only with close cooperation of citizens and public authority. However, the efficient cooperation is possible just in case when public authority is publicly-disclosed. Publicity in the activity of state and municipal bodies is the basis of democracy building. That is why publicity principle is currently becoming a subject of active discussion both among the representatives of government bodies and among scholars. We suggest that publicity cannot develop without appropriate legal basis enshrined in the sources of state law. At the same time when assessing publicity as a principle important for the development of local self-government, there is the necessity of studying the practice of legal control of publicity in particular countries, as well as scholars' views of publicity in different states.

When considering publicity principle in Russia it is necessary to pay attention to its interpretation in speeches and reports of government bodies and officials. Thus, President of the Russian Federation V.V. Putin pointed out the necessity of providing openness of information on the work of social welfare institutions in his Address to the Federal Assembly of December 4, 2014 (Putin, 2014). Russian Federation Civic Chamber in its Report on the Development of Civic Society in the Russian Federation for 2012 criticized "non-transparency" of utilities sphere in Russia.

As you can see from the material mentioned above, publicity is examined in "society - public authority" plane, whereas the main problem is presented by openness and transparency of functions and services provided by authority directly to the population, more simply, to every citizen of the state. Guided by such principles, we suppose it to be proved to study legal confirmation and publicity demonstration at the local level, i.e. at the level of municipal territories. The object of the research is publicity during the provision of municipal services to the population. The subject of the study shall include municipal administrative regulations controlling procedure for provision of such services. The objective of the work is to reveal publicity elements in municipal administrative regulations of the Russian Federation and their comparison with publicity elements during control of similar institution in foreign countries. Study and analysis of the Russian legislation, brief review of legislation of foreign countries and appeal to the works of Russian and foreign scholars are cross-cutting tasks of the present research. 


\section{Methods}

The solution of the tasks set in the research requires the use of a set of scientific methods subdued to the unified system of principles. The research techniques will be subdued to the following principles: scientific character, complexity, justification, legitimacy.

Among a set of research techniques and methods, general scientific methods shall be pointed out. First of all, they include a dialectical method. The use of analogy, synthesis, analysis will allow to assess the current state of the problem. Structured systematic approach gives the possibility to submit general characteristics of legal control institution for municipal services in Russia.

Among special juridical methods used in research we can name legalistic method used for the research of legal confirmation of publicity principle when regulating municipal services.

'The work will include doctrinal and legal comparative methods of problem study. Doctrinal method of study will help to find and analyze the works of legal scholars on the problem under study. Legal comparative method serves to compare legal basis of publicity at the local level in Russia and in foreign countries. As the topic under study is extensive, the research and further search of new solution approaches go beyond the enumerated methods. Thus, among special juridical methods used in research it is possible to distinguish legal drafting methodology - special language used when formulating legal norms, and ways of coping with loopholes and gaps in the law. Legal linguistics method of problem study, which will allow comparing the content of legal terms in different languages, plays a significant role in the research as well.

Data for study of the raised problem is the Russian legislation, legislation of foreign countries, scientific works of legal scholars of Russia and foreign countries.

\section{Results}

The results of the research obtained by the authors come down to the following. Both in the legislation of the Russian Federation and legislation of foreign countries publicity principle was confirmed. There are no legal acts controlling publicity principle, or legal definition of the notion "publicity", as a rule. At the same time the principle is revealed through the content of numerous legal norms talking about public control, public disclosure, openness, transparency, responsible attitude of authority to their functions.

In contrast with foreign science, Russian legal thought gives different definitions of the notion "publicity" and a foreign word "transparency" which is also included into the Russian legal language. In Russia scholars differentiate similar notions as "publicity", "transparency", "openness", and "public disclosure". At the same time both Russian and foreign legal thoughts reflect unified approaches to publicity which include the following important aspects.

First, the activity of public authority shall be open, and population shall know the information on their work.

Second, public authority is regulated by and accountable to the population.

Third, population opinion shall be taken into account when public authority makes decisions, at the same time the population has a real opportunity to influence the decisions taken, change them, assess them which will be acknowledged when making similar decisions in future (so called feedback).

Forth, the population possesses a specific kind of information on the activity of public authority - financial information, including data on budget administration.

All publicity components mentioned exist at the municipal level and become apparent when providing municipal services to the population.

Municipal services satisfy primary needs of citizens, that is why a degree of population's satisfaction with such services is one of the means of independent estimation of authority's activity at the local level. Municipal services sphere is the most dynamic and rapidly developing, as evidenced by the new ways of service provision - remotely, via the Internet. The modern ways of municipal service provision make this institution more open and public, and allow finding new possibilities to control activity of local self-government bodies.

In the Russian Federation the procedure for municipal service provision is controlled by a certain type of regulatory acts - administrative regulations of local self-government bodies. In foreign countries this institution is controlled differently, and such regulatory acts as administrative regulations are used in different spheres. In general, the practice of foreign states uses the term "regulation" for administrative regulations adopted by governments of, for example, France, Italy, and some other states in exercising regulatory powers, i.e. legal control of public relations by means of vesting legal legitimate rights in its members and imposing legal duties on them.

In the USA the term "administrative regulations" is used to name interaction rules within the department and 
between department and its clients. In Great Britain rules of department's work with the population is denoted by the term "standards of work with citizens" and includes the definition of indexes of work with population for public officials.

When observing as a whole, however the regulation is named, whatever procedure for municipal service provision is, and whatever the functions of municipalities for citizens' primary needs satisfaction are, the specified sphere is controlled in accordance with publicity principle expressed directly or indirectly. At the same time in some countries the institution under study is more public, in others - is less public.

\section{Discussion}

Publicity as a general legal category is a popular object of research both in foreign and Russian science. Among Russian scholars the following researchers of this phenimenon can be named: Z.S. Idrisova, Yu. Meshkova, Z.V. Makarova, I. Afonin, O. Moskvitina. The above mentioned researchers consider publicity as a phenomenon of federal level, they carry out their investigations within the frameworks of federal procedural law, both criminal and civil, as a rule.

V.I. Vasileyev is interested in publicity issues at the level of self-government and often touches upon publicity principle in his works. T.N. Mikheeva considers publicity principle in the interaction of government authority and local selfgovernment bodies (Mikheeva, 2012). Yu.S. Yaichnikova touches upon some publicity elements at the local level when studying the issues of public control of local self-government bodies. Publicity principle at the local level is presented in the works of D.S. Mikheev in the most consistent manner. In one of his works the scholar gives a detailed analysis of the notion "transparency" identifying it with the notion "openness". D.S. Mikheev considers it more acute to research transparency principle, its peculiarities and perspectives of future implementation in details. At first sight, the notions of publicity, openness and transparency may seem identical contentwise. But in fact they have different legal meaning. Upon closer analysis transparency serves as a notion with a wider content than publicity and openness, and covers all sides of arrangement of activity of civil service. In modern understanding the content of transparency principle is comprehensive, and all the terms used to characterize it serve as separate elements of this principle (publicity, openness, availability). Each of them may be considered as transparency demonstration.

Transparency (openness) shall be considered as a constitutional and legal principle of arrangement and functioning of public authority system and its separate body. Its content is that public authority bodies provide the fullest information on their activity to the citizens in different forms, as well as sometimes resort to consultancies with the citizens and civic institutions during elaboration and making arbitrary decisions. (Mikheev, Mikheeva, 2013)

The opinion of foreign scholar Axel Gosseries conforms to the quoted position. He claims that by transparency, broadly understood, we refer to the way that such institutions operate under public scrutiny. This will typically entail the possibility for (groups of) citizens to access documents produced by representatives or civil servants, or the possibility of witnessing deliberative processes in action, e.g. in parliamentary assemblies. Yet, the precise effects of transparency and the exact function it plays in such a democratic setting are still not entirely clear, despite the fact that the public generally tends to consider transparency as having globally positive effects on democracies. (Axel Gosseries, 2006)

Transparency is considered as a key factor of governmental reliability by Stephan Grimmelikhuijsen, Gregory Porumbescu, Boram Hong, and Tobin Im in their work The Effect of Transparency on Trust in Government: A CrossNational Comparative Experiment. Their research is essential because they consider transparency in terms of national traditions and culture, comparing an effect of transparency on trust in government in the Netherlands and South Korea. (Grimmelikhuijsen, Porumbescu, Hong and Im, 2013).

The work of Frank Bannister and Regina Connolly The Trouble with Transparency: A Critical Review of Openness in e-Government is worth to be noted in relation to the research of availability issue of electronic government in Russia. In this work the authors examine the argument that transparency may, in certain and not uncommon circumstances, be inimical to good government and good governance and suggests that the importance of understanding why this is so has increased as information and communications technology permeates government and society. It suggests that in an electronic age, the scope and nature of transparency needs to be carefully managed, and that expectations of the benefits of ICT enabled transparency may be too high. (Bannister, Connolly, 2011).

Foreign literature also has some research devoted to transparency issues at the municipal level. Thus, the research Transparency and Political Budget Cycles at municipal level is devoted to the problem of the effect of municipal financial transparency on the magnitude of political budget cycles. (Vicente, Benito and Bastida, 2013).

It is necessary to note that in contrast with their foreign colleagues, Russian scholars consider publicity at the level of local self-government in a broader sense. Thus, for example, D.S. Mikheev analyzes the norms of European Charter Treaty of local self-government from the perspective of publicity confirmation as a key principle of local self-government. The author points out that this principle was not directly confirmed in the Charter Treaty. (Mikheev, 2014). 
The discussed issue of publicity when regulating municipal services is addressed in scientific research only by D.S. Mikheev. Other researchers study this issue just indirectly. Thus, O.V. Yachina, N.S. Vavilov, and D.S. Mikheev considered nonseparability of local self-government bodies and civic institution in the process of service provision and implementation of public control of their provision in their work Availability of Municipal Services as a Means of Communication of Municipal Authorities and Citizens. The article also touches upon the issues of services availability and municipal regulations transparency. (Yakhina, Vavilov, Mikheev, 2015).

Interesting analysis of German law from the point of view of publicity is presented in the research On the Experience of Legal Regulation of the Principle of Publicity of Local Authorities in German Law (Mikheev, Mikheeva, Mokoseeva, 2015).

Therefore, publicity principle, and its confirmation in legal acts in particular which regulate procedure for municipal services provision (administrative regulations), received little attention in science. At the same time public authority assessment and trust depend on how these services are provided to the population. It is no wonder that power which is able to satisfy primary needs of people is more efficient, from the point of view of population. But to satisfy citizens' needs the procedure for municipal services provision shall be more open and public. As a consequence, administrative regulation of municipal services shall be public as well.

The analysis of norms of the Federal Law of July 02, 2010 No. 210-FZ "On the Organization of State and Municipal Services" and Federal Law of October 06, 2003 No. 131- FZ "On the General Principles of the Organization of Local SelfGovernment in the Russian Federation" did not show direct confirmation of publicity principle when regulating municipal services. However, absence of such confirmation does not give evidence of disregard to this principle. It is presented by means of such norms as online publishing of administrative regulation project, opportunity to carry out independent examination of administrative regulation project by legal entities and individuals, service provision in multifunctional centers.

While analyzing similar legal standards in foreign legislation we find publicity principle confirmation when regulating municipal services. For example, the provision, that local authority reports to the population at least every other year on the content and volumes of the provided services, as well as on the factors to be reached when providing the corresponding services, is confirmed in the Law On Self-Government in Denmark and may be considered as one of the principles for providing municipal service. Similar norms of information provision are mentioned in the Finnish legislation. Among positive aspects of Finnish legislation in municipal service sphere it is necessary to point out feedback mechanism implementation (between municipality and population), rectification system in the work of local bodies and organizations providing the corresponding services.

We observe successful practices of publicity principle confirmation when regulating municipal services in the legislation of foreign countries by means of implementation of feedback aspect into legal norms. This aspect has not been confirmed in the Russian legislation yet. We consider it necessary to update the article 13 of the Federal Law of July 02 , 2010 No. 210-FZ "On the Organization of State and Municipal Services" with legal norm to obligate the authorized body to evaluate and make reasoned decision following the independent examination of administrative regulation project.

\section{Conclusion}

Based on the results of research of publicity in regulation of municipal services, the authors made a number of conclusions coming down to the following. Publicity principle is a dynamically developing legal category as evidenced by the interest from scholars and the existence of elements of this principle in the acting legislation. In the Russian legal language the notions "publicity", "openness", "public disclosure" are usually used, whereas foreign notion "transparency" unites the mentioned categories. Despite such differences all scholars embed similar sense into this notion and use the same elements to explain it.

Publicity principle implemented in municipal legal acts increases the efficiency of self-government, and promotes population trust building. Publicity principle is confirmed clearer and deeper in the self-government legislation of foreign countries. Russian Federation law has similar provisions, however, publicity principle is not confirmed so fully, and such important elements as feedback between authority and population do not exist. That is why the authors judge it expedient to continue research within the framework of sourcing of legal control at the local level. It should include publicity elements, as indicated by good regulation practices in foreign states. Besides, the authors suggest to the legislator to consider the confirmation issue of publicity principle when providing municipal services at the federal level. 


\section{Acknowledgements}

The authors want to express gratitude to the Federal State Budgetary Institution "Russian Humanitarian Scientific Foundation" (URL: http://www.rfh.ru/index.php/ru/) for the support of the project ("a2" type project) "Innovative approaches and mechanisms of realization of publicity in the activities of local authorities" during the competition for young scholars support for the year 2015 (project supervisor Denis S. Mikheev, performers: Olga V. Yakhina, Valentin V. Kudryavtsev, Julia S. Yaichnikova), project number is 15-33-01364.

\section{References}

Bannister, F., Connolly, R. (2011) The Trouble with Transparency: A Critical Review of Openness in e-Government. Policy \& Internet, Volume 3, Issue 1, 1-30. http//dx.doi.org/ 10.2202/1944-2866.1076.

Federal Law of 02.07.2010 \# 210-FZ "On the Organization of Provision of the State and Municipal Services", [Online] Available: http://base.consultant.ru/cons/cgi/online.cgi?req=doc;base=LAW;n=165305;div=LAW;mb=LAW;opt=1;ts=2D95C7F2C583C702B 80CA66AB25539C1.

Federal Law of 06.10.2003 \# 131-FZ "On General Principles of the Organization of Local Self-Government in the Russian Federation", [Online] Available: http://base.consultant.ru/cons/cgi/online.cgi?req=doc;base=LAW;n=166232;div=LAW;mb=LAW;opt=1;ts=34F 43B0351E9868E76E73BAD14F86FAE

French, P. Edward (2003). Municipal Government: Does Structure Make a Difference in Small Cities and Towns? Politics and policy, Volume 31, Issue 4, 694-725, http//dx.doi.org/ : 10.1111/j.1747-1346.2003.tb00168.x

Gosseries, A. Democracy and Transparency. Swiss Political Science Review, Volume 12, Issue 3, 83-90. http//dx.doi.org/10.1002/j. 1662-6370.2006.tb00056.x

Grimmelikhuijsen, S., Porumbescu, G., Hong, B., Im, T. (2013) The Effect of Transparency on Trust in Government: A Cross-National Comparative Experiment. Public Administration Review, Volume 73, Issue 4, http//dx.doi.org/ 10.1111/puar.12047

Mikheev, D.S., Mikheeva, T.N., Mokoseeva, M.A. (2015). On the experience of legal regulation of the principle of local authorities in German law. Review of European Studies. Volume 7, No 8, 23-27, http//dx.doi.org/: 10.5539/res.v7n8p23

Mikheev, D.S. (2013). On the Directions of Democratization of Municipal Election Process. In Municipal Services: Legal Matters. \# 1, 3.

Mikheev, D.S. (2014). Legal analysis of the European charter of local self-government in the light of the principle of publicity, Life Science Journal, 11(6), 619-622.

Mikheev, D.S., Mikheeva, T.N. (2013). Formation and Functioning of Interaction System of Civil Service in Mari El Republic with Civic Institutions. Yoshkar-Ola.

Mikheeva, T.N. (2012). The Peculiarities of the Contemporary Institution of Local Self-Government in the Russian Federation. In Eurasian Law Journal. 2, 58-59

Mikheeva, T.N. (2014). Novels in the legal regulation of local government, Constitutional and municipal law,9.

Putin, V.V. (2014). Address of RF President Vladimir Putin to the Federal Assembly of 04.12.2014 (2014), Rossiyskaya Gazeta, 278.

Russian Federation Civic Chamber, (2012). Report on the Development of Civic Society in the Russian Federation for 2012 [Online] Available: http://lockeclub.org/wp-content/uploads/2013/06/O_sostojanii_grazhdanskogo_obshhestva_v_RF_Doklad_OPRF_ 2012. pdf

Shabadarova, O.V. (2014). An Administrative Provision as a Regulatory Act in the System of Municipal Regulations. Law and Justice. $11,54-56$.

Vicente, C., Benito, B., Bastida, F. (2013). Transparency and Political Budget Cycles at municipal level. Swiss Political Science Review, Volume 19, Issue 2, 139-156. http//dx.doi.org/ 10.1111/spsr.12036.

Yakhina, O., Vavilov, N., Mikheev, D. (2015). Availability of Municipal Services as a Means of Communication of Municipal Authorities and Citizens. Review of European Studies, Volume 7, No 8, 227-232, http//dx.doi.org/: 10.5539/res.v7n8p227 
